\title{
Priorities of Agricultural Utilization for Some New Areas of El-Minia Governorate Desert fringe - Egypt
}

\author{
Taher, M. H. Yossif, Mohamed. E. A. Khalifa and Ahmed S. A. Sayed \\ Pedology Dept., Water Resources and Desert Soils Division, Desert Research Center, \\ Cairo, Egypt.
}

Corresponding author: Mohamed. E. A. Khalifa, m ezzat28@hotmail.com

\begin{abstract}
Due to the continuous decrease of agricultural lands, it is necessary to identify the most relevant lands for sustainable agriculture development at desert areas in which being socially equitable. The main objective of this study is to determine priorities of agricultural utilization for some areas at the western desert fringe of El-Minia Governorate. The selected area is bounded by longitudes $30^{\circ} 30^{\prime} 00^{\prime \prime} \mathrm{E}$ and $30^{\circ} 45^{\circ} 00^{\prime \prime} \mathrm{E}$ and latitudes $28^{\circ} 26^{\prime} 56^{\prime \prime} \mathrm{N}$ and $28^{\circ} 46^{\prime} 1^{\prime \prime} \mathrm{N}$, covering an area of approximately 124691 feddan. It includes five new village of El-Minia namely; new Al-Atf, new Ash ShaykhMas'ud, new Al-Bahnasa, new Al-Hema and new Abu Algod villages. Soils of the area were surveyed using 90 profiles. Seventeen soil profiles were chosen to represent dominant landforms of the area. Soil samples were collected for further laboratory analysis to determine their properties. Based on ground truth data, laboratory analysis and imagery interpretation in cooperation with geographic information system (GIS) utilities, the geomorphic map was generated and nine geomorphic units could be differentiated. These are; pediment; alluvial fans and outwash plains; upper, moderate and lower rubble terraces; old river terraces; dissected plateaus; wind-blown sand dunes; hilly areas and rock out crops. Soils of these landforms were investigated and classified mainly as Lithic Torripsamments, Typic Torripsamments, Typic Torriorthents, Typic Haplogypsids, Calcic Haplosalids, and Typic Haplocalcids subgroups. They were grouped into four soil mapping units varying in soil depth and gravel content. Land capability was assessed to define the most suitable areas for agricultural production using MicroLEIS microcomputer program (CERVATANA capability model). Soils of the area classified into two capability classes, moderate-S $(37.1 \%)$ and non productive- $\mathrm{N}(36.13 \%)$, while rest of the area belong to dissected plateau, hilly terrain and dunes. Further, three capability subclasses were recognized abbreviated as S3 I, S3 Ir, and N I in accordance to limitations type and severity. Priorities of Agricultural Utilization Model (PAUM) was designed. Four priority grads were identified where the first priority in the studied area occupy $25.84 \%$ of the total terrain and belongs mainly to soils of alluvial fans and outwash plains, lower rubble terraces, and partially old river terraces. Only new AshShaykh Mas'ud village belongs to the first priority for agricultural utilization, while, other investigated villages were classified as third priority. The study is considered of vital importance for decision makers through the management of natural resources in desert fringe.

Key Words: El-Minia Governorate, desert fringe, soil characteristics, land capability, agricultural utilization priorities.
\end{abstract}

\section{INTRODUCTION}

In the framework of the steps taken by the Egyptian government to preserve the agricultural land from infringement risks through urban encroachment, the Ministry of Housing, Utilities and Urban Communities have been selected new areas to establish a national project to develop the desert fringes of old cities and villages. That mega project started in 2007 aiming to create about 400 new villages 
of the Delta and the Nile Valley desert fringes. New urban or rural communities are planned to increase the cultivated area of Egypt, thus preserving the agricultural land. Twenty four locations were chosen at the desert fringes of El-Minia Governorate to develop new villages. These locations at the western desert fringe of El-Minia could be considered the most important horizontal expansion at Middle of Egypt. From agricultural point of view, DRC staff (2014) found obvious soil constrains associated to some areas of selected new villages; such as rough topography, soil shallowness, coarse texture soils, extremely lime content, soil salinization and sand dunes encroachment.

The area under investigation is located to the west of the Nile Valley within El-Minia desert fringes. It extends from west of Matai district in the south to west of Al-Idwah district in the north; bounded by longitudes $30^{\circ} 30^{\circ} 00^{\prime} \mathrm{E}$ and $30^{\circ} 45^{\circ}$ $00^{\prime \prime} \mathrm{E}$ and latitudes $28^{\circ} 26^{\prime} 56^{\prime \prime} \mathrm{N}$ and $28^{\circ} 46^{\prime} 1^{\prime \prime} \mathrm{N}$, covering an area of approximately 124691 feddan. The area continue northward, widening from about $5 \mathrm{~km}$ near Matai district in the south to about $9 \mathrm{~km}$ at latitude of Dahrut and then gradually narrowing again to some $4 \mathrm{kms}$, just west of Al-ldwah district in north. The area includes five locations of new villages over about 2857, 2380, 2142, 1760 and 2285 feddan; namely, new Al-Atf, new Ash Shaykh Mas'ud, new Al-Bahnasa, new Al-Hema and new Abu Algod villages, respectively (Map 1).

Said (1993) mentioned that in the western side of the Nile valley, the middle Eocene formations are covered by Oligocene gravels and cobbles. The Eocene limestone may crop to the surface locally. The main geological deposits in the study area are Nile deposits, sand dunes, aeolian deposits, gravels and basalt, (Egyptian General Petroleum Corporation - Conco Coral Staff, 1987). According to Abu El-Izz (2000) the investigated area is built of recent alluvium sediments belong to Pleistocene, and Pliocene periods. The area is characterized by arid climate as the total rainfall is (4-7.8) $\mathrm{mm} /$ year. The dryness is prevailing most of the year and the wet periods are comparatively short. Based on the Egyptian Meteorological Authority data (2000-2009) and USDA Soil Survey Staff (2010), the soil temperature regime of the studied area is defined as Thermic, and the soil moisture regime as Torric. Ground water is considered the main source of irrigation water in the study area.

The availability of advanced technologies, for managing significant quantities of data, should help the planers and decision makers to organize the information, understand their spatial association, and provide a powerful means for analyzing and synthesizing the related information. Moreover, the launching of space-born satellite is powerful in gathering and managing information about the state of land using remote sensing (RS) and Geographic Information System (GIS). Applying the powerful capabilities of advanced RS and GIS techniques through integrating spatial data contribute in terrain analyzing, as well as generate a digital soil information layers. The aim of this study is to evaluate soils of some areas at the western desert fringes of El-Minia Governorate for producing digital land capability map as a base of defining priorities of agricultural utilization. 

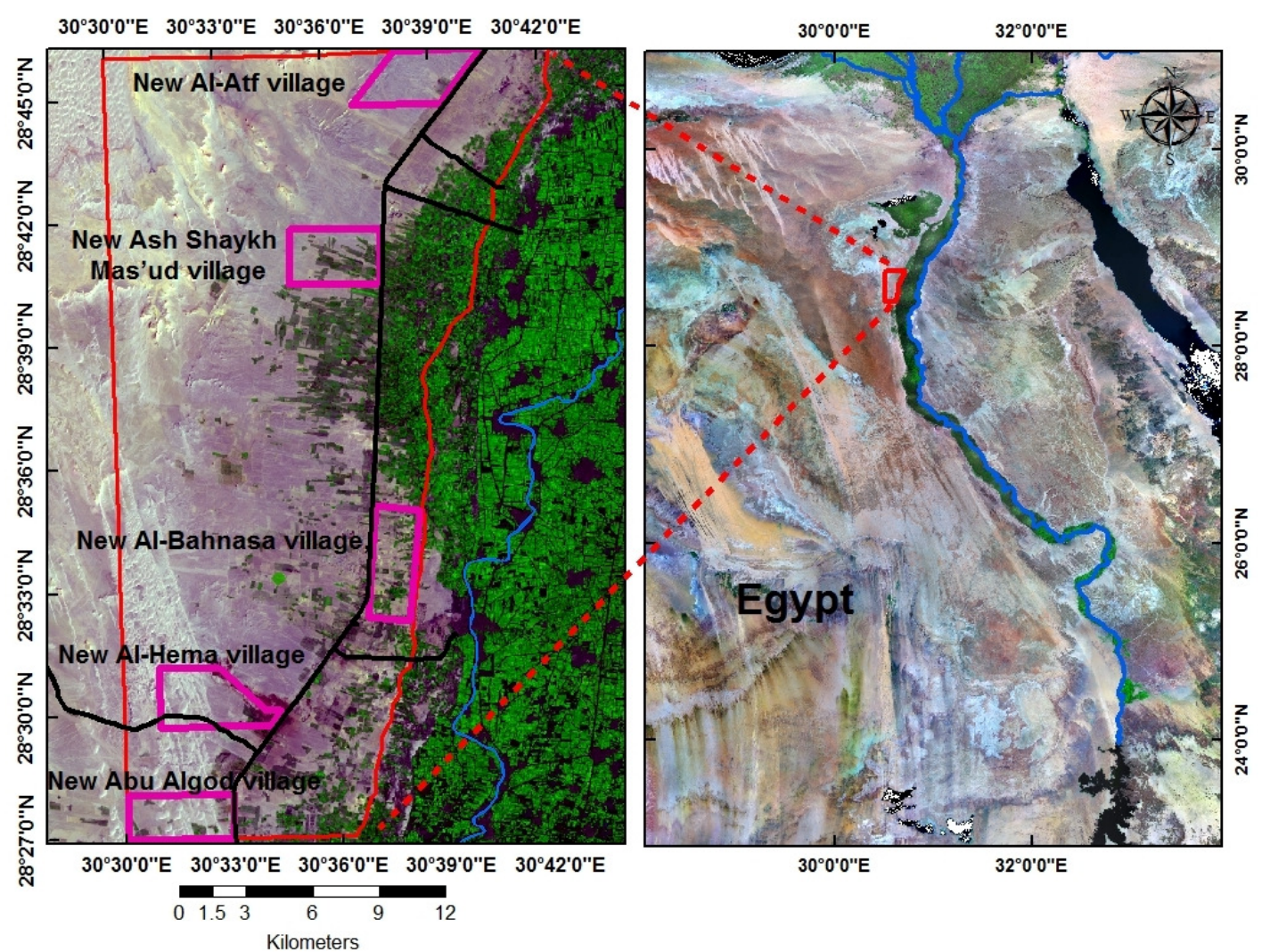

Map (1). Location of the studied area at the western desert fringe of El-Minia.

\section{MATERIALS AND METHODS}

A Landsat-8OLI image acquired in 2016 (path 176 / row 40) was employed in this study. It was processed using ERDAS Imagine 9.3 software (2010) with a generated Digital Elevation Model (DEM) based on vector contour lines (Map 2). DEM was successfully used to identify different landforms of the study area and to gain an appreciation of the landscape characteristics (slope gradient).

A semi-detailed soil survey (DRC Staff, 2016) was made throughout the investigated area, including five new village's areas of El-Minia Governorate western desert fringes. Soil survey was undertaken in order to identify and verify the major landform and to gain an appreciation of the broad soil patterns and landscape characteristics. The primary mapping units were verified based on the field interpretation and the information gained during the survey. A total of 90 soil profiles were spatially distributed over the area under consideration in addition to some auger observations were taken to represent the delineated mapping units and to fulfill the requirements of digital mapping (DRC Staff, 2016). A detailed morphological description was recorded on the basis of guidelines for soil description, FAO (1990). Seventeen soil profiles were selected in the current study to represent the spatial extend of different landforms. 
The collected soil samples were subjected to some physical and chemical analyses using soil survey laboratory methods manual, USDA (2014). Soil classification was carried out according to the USDA Soil Taxonomy, USDA Soil Survey Staff (2010).

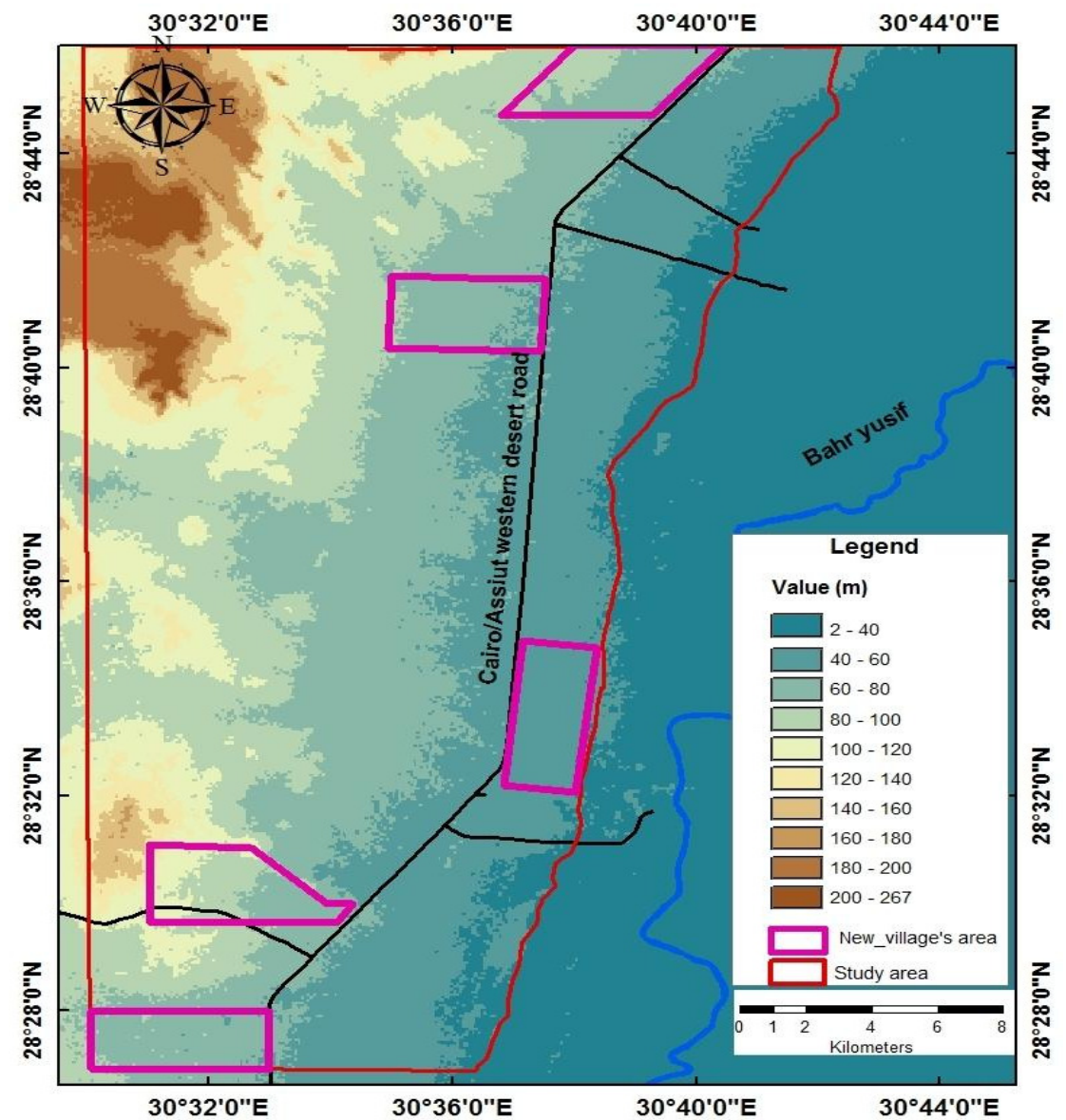

Map (2). Digital Elevation Model of the studied area.

A land capability evaluation was applied using CERVATANA model constituent of MicroLEIS DSS. This model was designed by De la Rosa et. al. (1992) and modified for computing purpose by De la Rosa et al. (2004). Following the generally accepted norms of land evaluation (Klingebiel and Montgmery, 1961; FAO, 1976; Dent and Young, 1981; ONERN, 1982; and Verheye, 1986), the CERVATANA model forecasts the general land use capability or suitability for a broad series of possible agricultural uses. That model works interactively, comparing the values of the characteristics of the land-unit to be evaluated with the generalization levels established for each Use Capability Class. The prediction of general land use capability is the result of a qualitative evaluation process or 
overall interpretation of the following biophysical factors: relief, soil, climate, and current use or vegetation (Fig. 1).

Priorities of Agricultural Utilization Model (PAUM) was designed and processed using spatial modeling environment of Arc GIS software, ESRI (2010). Soil, geomorphologic, land capability and agricultural utilization priorities maps were spatially generated using Arc GIS software, ESRI (2010).

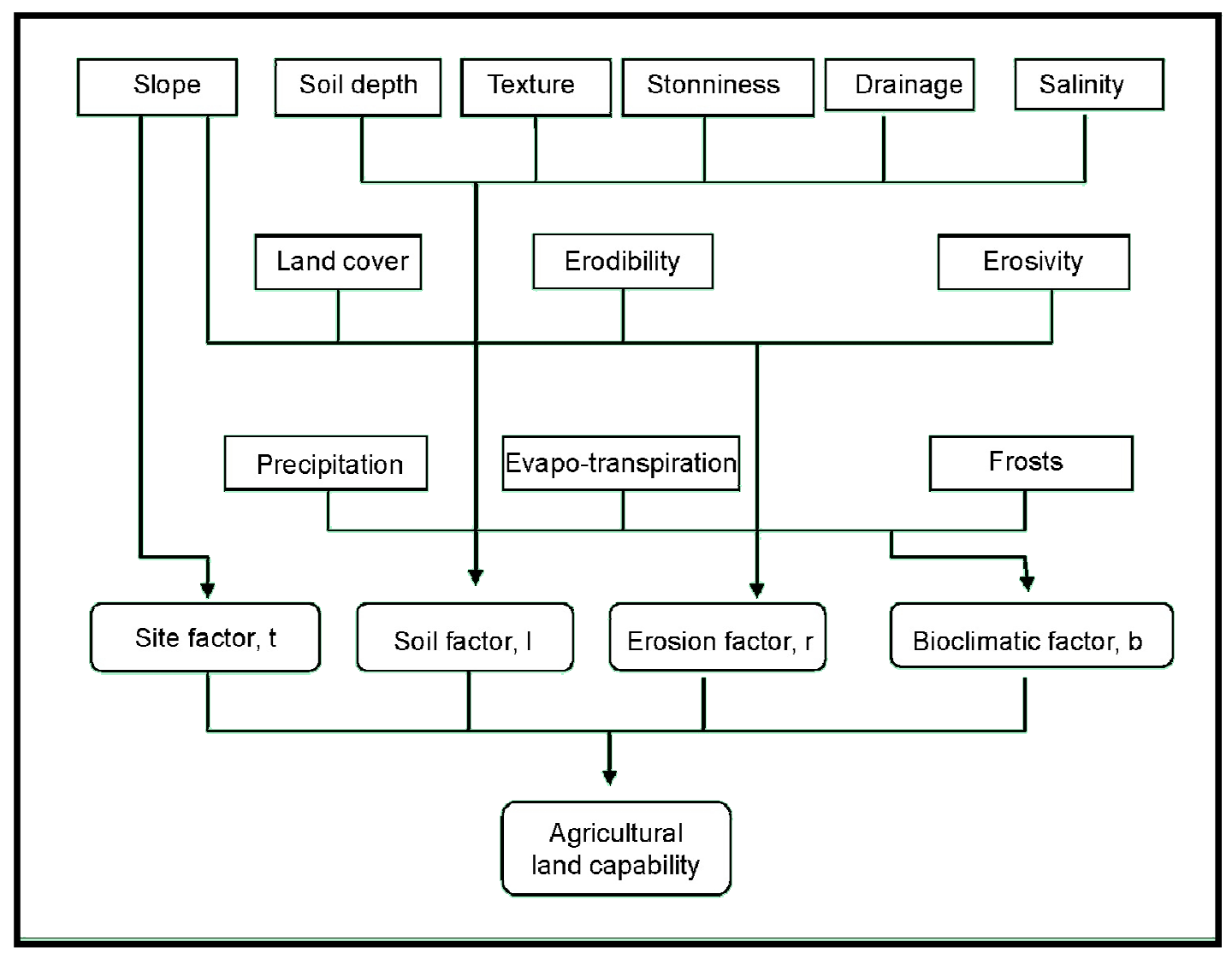

Fig.(1). Flowchart of data processing using CERVATANA model constituent of MicroLEIS DSS.

\section{RESULTS AND DISCUSSION}

\section{A- Geomorphology of the investigated area}

Based on the visual interpretation of merged DEM with OLI image together with knowledge driven from the geological map (Egyptian General Petroleum Corporation Conco Coral Staff, 1987), topography map, ground truth data and soil survey of the study area, the main landforms were delineated (Map 3). They could be recognized as 1-Dissected plateau 2-Pediment 3-Alluvial fans 4-Lower rubble terraces 5-Moderate rubble terraces 6-Upper rubble terraces 7-Old river terraces 8- 
Sand dune 9-Hilly area and rock out crops. Landforms map was considered a Geodatabase map over which the representative soil profiles were spatially distributed. Table 1 gives the proportions of each landform and associated soil profiles.

The area under investigation, part of El-Minia Governorate western desert fringes, consists largely of rubble and river terrace soils in addition to soils of alluvial fans and outwash plains. The rubble terrace soils dominate the area of desert fringe, having the same conspicuous sloping character as seen from the Nile valley. The rubble terrace soils are interrupted, and covered in three places by fan and outwash deposits. They are gently undulating at surface than those of river terrace present in the study, and sometimes have extremely gypsiferous profiles.

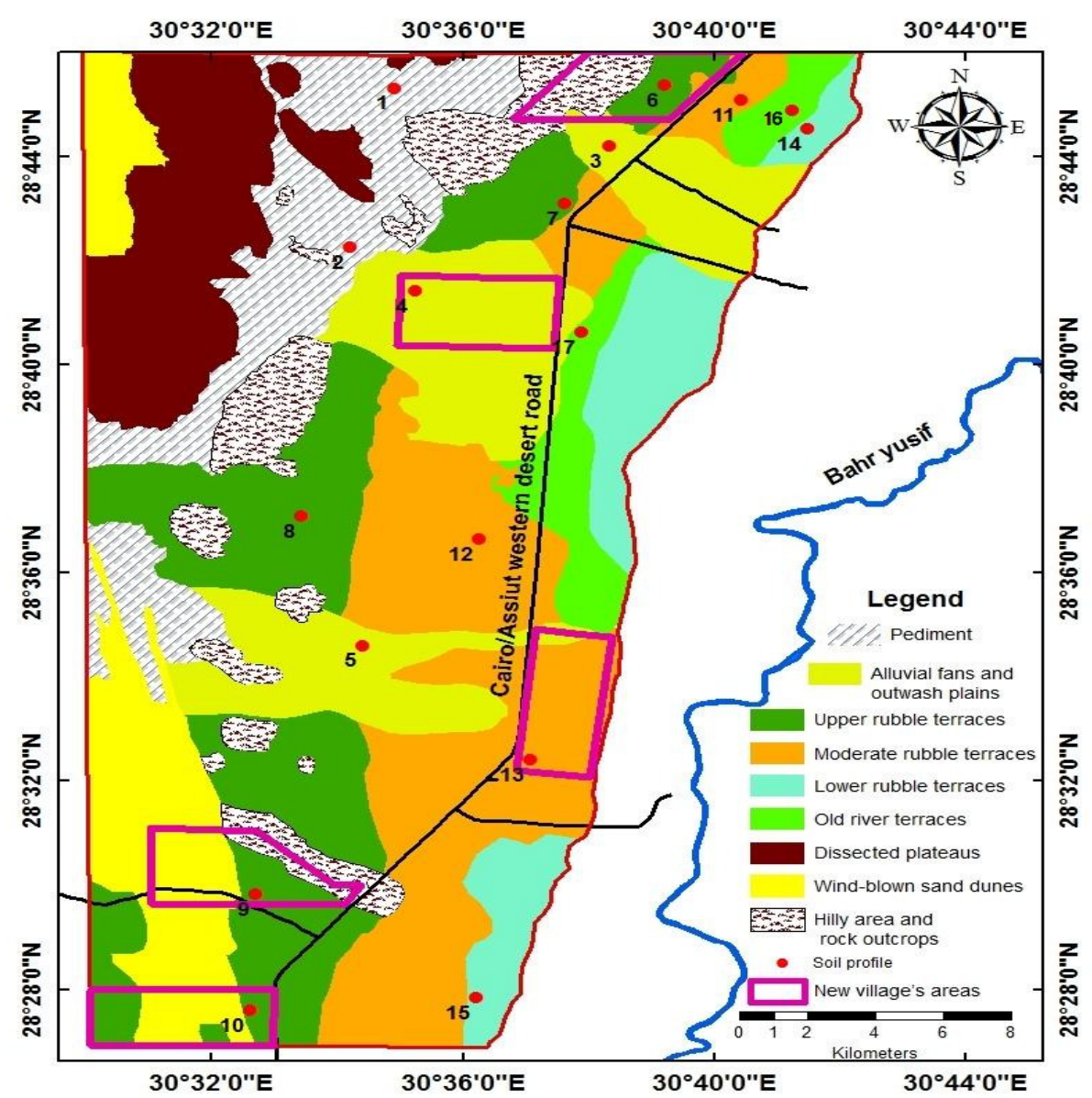

Map (3). Main landforms of the studied area. 
Table (1). Main landforms and its areas in the study location.

\begin{tabular}{lcccc}
\hline \multicolumn{1}{c}{ Landform } & $\begin{array}{c}\text { Representative } \\
\text { soil profile }\end{array}$ & $\begin{array}{c}\text { Max. } \\
\text { Elevation }\end{array}$ & $\begin{array}{c}\text { Area } \\
\text { feddan }\end{array}$ & (\%) \\
\hline Pediment & $1-2$ & 162 & 13094 & 10.5 \\
Alluvial fans and outwash plains & $3-4-5$ & 95 & 19118 & 15.34 \\
Upper rubble terraces & $6-7-8-9-10$ & 101 & 20652 & 16.56 \\
Moderate rubble terraces & $11-12-13$ & 77 & 24405 & 19.57 \\
Lower rubble terraces & $14-15$ & 49 & 8665 & 6.95 \\
Old river terraces & $16-17$ & 58 & 5400 & 4.33 \\
Dissected plateaus & & 267 & 12075 & 9.68 \\
Wind-blown sand dunes & & 260 & 11974 & 9.6 \\
Hilly areas and rock out crops. & & 96 & 9308 & 7.46 \\
\hline \multicolumn{1}{c}{ Total } & & & $\mathbf{1 2 4 6 9 1}$ & $\mathbf{1 0 0}$ \\
\hline \multicolumn{2}{c}{$\quad$}
\end{tabular}

Soils of river terrace occurred generally in lower terrain with high gravel contents. Locally they may show strong gypsum accumulations in the profile or somewhat reddish subsoil colors due to ferric oxides. As a result of their higher altitude, the relief is somewhat more undulating to even sometimes rolling. Alluvial fan and outwash plain soils are generally of a deep slightly gravelly sandy nature. This may be attributed to the great run-off depositional regime from the pediment lands and/or from the northwestern soft middle Eocene rocks than that from the southwestern Oligocene cobble land.

The dissected limestone plateaus stand out locally at the western north part of the study area and occupy a large area with steep scarps. Most of the plateau area is occupied by exposed soft middle Eocene formations, except for some scattered portions are covered by sand dunes. Whole plateau formations, in particular the shales and shaly clays, appear to be very saline and gypsiferous. The characteristics of the dissected limestone plateaus are affecting the desert fringe soils. North of Maghagha, very few remnants of the Oligocene cobble formation are found (isolated hills and rock out crops).

Soils of the wind-blown sand dunes were formed over higher land at the western boundaries of the study area. They overlie either the middle Eocene or denuded Oligocene formations. These soils were originated from the soft middle Eocene sandstone, which is exposed to weathering south of El Fayum depression, carried by the prevailing northerly winds. They sometime form elongated seif - or sword-dunes (longitudinal shape) with sheets of sand in between.

\section{B- Soils of the investigated area}

The area under study has different morphological, physical and chemical characteristics according to studied soil profiles representing the different landforms. Tables 2 and 3 show values of soil attributes which could be classified according to Soil Taxonomy (USDA, Soil Survey Staff, 2010) and discussed as the following: 


\section{1- Soils of Pediments}

Studied soils of this unit were formed at the down of a rock escarpment of the dissected limestone plateaus in the northwestern of the study area, dated back to middle Eocene age. They occupy an area of about 13094 feddan covering 10.5 $\%$ of the total area and represented by soil profiles No. 1 and 2 . The surface is undulating, sloping towards the east, and covered with many fine gravels. Surface runoff and associated hazard of water erosion are slight due to dominant gentle slope. The data show that soils have shallow depth lays between 35 and $45 \mathrm{~cm}$ due limitation by a lithic contact. Soil texture is sand throughout the different layers of representative soil profiles, and $\mathrm{pH}$ values indicate slightly alkaline condition. They are characterized by very slightly to slightly saline soils as electric conductivity values ranged between 2.9 and $6.9 \mathrm{dS} / \mathrm{m}$. Meanwhile, soils of pediment possess relatively high content of $\mathrm{CaCO}_{3}$. The soils of this unit are classified as Lithic Torripsamments.

\section{2- Soils of alluvial fans and outwash plains}

Soils of this unit cover an area of about 19118 feddan, representing $15.34 \%$ of the total area and represented by soil profiles No. 3, 4, and 5. They are derived from the high-lying lands of the dissected limestone plateaus which located at west of the study area. The surface is almost flat, gently sloped towards east direction, and is covered with many fine gravels. The hazardous effect of water erosion is slight as surface runoff is very slow due to slight slope class. The soils are deep and characterized by coarse texture, excessively drainage, and slight to moderate alkalinity. Variable levels of salinity are noticeable depending on the site topography. Secondary formations of carbonates and gypsum in detectable amount were identified throughout the layers with no any characteristics of diagnostic horizons. With a few exceptions they are gravelly sand in deep layers. Based on analytical data and field studied soils of alluvial fans and outwash plains are classified as Typic Torripsamments.

\section{3- Soils of Rubble terraces}

The rubble terrace soils occupy most of the study area as they cover about 53722 feddan representing $43.08 \%$ of the total area. They are developed from the pediment land and/or the soft middle Eocene rocks at west of the study area. Soils of rubble terraces are considered a transition zone between the eastern river terrace deposits and the western dissected limestone plateau. They are formed from sandy to gravelly sand soils. Surface is almost flat to gently undulate which minimize surface runoff with slight hazard of water erosion. They are divided into different subdivisions according to their physiographic position as follow:-

\section{1- Soils of upper rubble terraces}

The upper rubble terraces cover an area of 20652 feddan representing $16.56 \%$ of the total studied terrain. Their formation may be affected by the adjacent rocky area, which rendered those terrace soils extremely gypsiferous. Soils of this landform were examined by soil profiles No. 6, 7, 8, 9, and 10. The surface is gently undulating and covered with gravels associated to desert varnish. 
They are excessively drained and characterized by deep gravelly sand profile. Soil reaction is slight tend to moderately alkaline range where $\mathrm{pH}$ values fluctuate between 7.4 and 8.2. Soils have wide range of salinity where EC values ranging between 6.24 and $54.47 \mathrm{dSm}^{-1}$. Relatively high content of total $\mathrm{CaCO}_{3}$ occurred in accordance to the nature of parent material. Gypsum secondary formation was detected in some profile horizons in which the characteristics of diagnostic horizon are recorded. Hence, soils are classified as Typic Haplogypsids.

\section{2- Soils of moderate rubble terraces}

Soils of this unit occupy the largest extent of the rubble terraces. They cover an area of 24405 feddan representing $19.57 \%$ of the total area and studied through profiles No. 11, 12 and 13. Surface is almost flat to gently undulated and mostly covered with desert pavement of gravels. They are characterized by deep gravelly sand profile with excessively drainage. The soils are slightly to moderately alkaline, highly calcareous, and extremely saline. Characteristics criteria of calcic and salic horizons in some layers were identified; therefore, they are classified as Calcic Haplosalids and Typic Haplocalcids.

\section{3- Soils of lower rubble terraces}

The lower rubble terraces soils cover an area of 8665 feddan representing $6.95 \%$ of the total area. The surface is almost flat and covered with rock grits with common fine gravels. They are represented by soil profiles No. 14 and 15 . These soils are characterized by deep sand profile with excessively drainage status. Values of $\mathrm{pH}$ indicate neutral to slightly alkaline tendency, and soils concerning salinity are classified as slightly salt affected soils throughout representative profiles. Accumulation of lime secondary formation in some profile horizons was detected. Characteristics criteria of calcic diagnostic horizons were found; hence they are classified as Typic Haplocalcids and Typic Torripsamments.

\section{4- Soils of old river terraces}

This unit is the remnants of Nile deposits at different altitudes and occupying small and elongated portion in the eastern north part of the study area. Soils of this unit are mostly identical in origin and composition with Nile alluvium soils. They cover an area of about 5400 feddan representing $4.33 \%$ of the total area, having an undulating surface covered by desert pavement, and a wide elevation range from 40 to $50 \mathrm{~m}$ above sea level. The hazard of water erosion is expected to be slight according to moderate surface. They are represented by soil profiles No. 16 and 17 which have deep drainable soil profile. Soils are very gravelly coarse sand in texture. $\mathrm{pH}$ values ranged from 7.4 to 7.8 indicating slightly alkalinity throughout the different layers of representative soil profiles. These soils are slightly to moderately saline where EC values ranging between 3.55 and $8.1 \mathrm{dS} / \mathrm{m}$. Total carbonate content is moderate and ranging between 5.15 and $10 \%$ due to the nature of parent material which consists essentially of Nile alluvium sediments, while gypsum content is null. They are placed as Typic Torriorthents. 
J. Adv. Agric. Res. (Fac. Agric. Saba Basha)

Table (2). Main morphological characteristics of representative soil profiles in the studied area.

\begin{tabular}{|c|c|c|c|c|c|c|}
\hline \multirow{2}{*}{ Prf. No. } & \multirow{2}{*}{$\begin{array}{l}\text { Lat. (N) } \\
\text { Long. (E) }\end{array}$} & \multirow{2}{*}{$\begin{array}{l}\text {-Topography, } \\
\text {-Slope, } \\
\text {-Surface cover }\end{array}$} & \multirow{2}{*}{$\begin{array}{l}\text {-Erosion, } \\
\text {-Drainage }\end{array}$} & \multirow{2}{*}{$\begin{array}{l}\text { Depth } \\
\text { (cm) }\end{array}$} & \multicolumn{2}{|c|}{ Soil color } \\
\hline & & & & & Dry & Moist \\
\hline \multicolumn{7}{|c|}{ Pediment } \\
\hline \multirow{2}{*}{1} & $28^{\circ} 45^{\prime} 18.53 "$ & \multirow{4}{*}{$\begin{array}{c}\text {-Undulating, } \\
\text {-Sloping, } \\
\text {-Many fine gravels } \\
\text { with ripple mark }\end{array}$} & \multirow{4}{*}{$\begin{array}{c}\text {-Moderate, } \\
\text {-Poorly }\end{array}$} & $0-20$ & 10YR 6/4 & 10YR $5 / 4$ \\
\hline & $30^{\circ} 34^{\prime} 56.16^{\prime \prime}$ & & & $20-35$ & 10YR 6/4 & 5YR 5/4 \\
\hline \multirow{2}{*}{2} & $28^{\circ} 42^{\prime} 15.41^{\prime \prime}$ & & & $0-25$ & 10YR 6/6 & 10YR 5/8 \\
\hline & $30^{\circ} 34^{\prime} 13.82^{\prime \prime}$ & & & $25-45$ & 10YR $6 / 6$ & 10YR 5/8 \\
\hline \multicolumn{7}{|c|}{ Alluvial fans and outwash plains } \\
\hline \multirow{3}{*}{3} & & \multirow{9}{*}{$\begin{array}{c}\text {-Almost flat, } \\
\text {-Nearly level, } \\
\text {-Many fine gravels }\end{array}$} & \multirow{9}{*}{$\begin{array}{l}\text {-Slight, } \\
\text {-Excess. }\end{array}$} & $0-20$ & 10YR 7/6 & 10YR 6/6 \\
\hline & 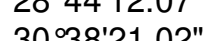 & & & $20-80$ & 10YR $7 / 6$ & 10YR $6 / 6$ \\
\hline & & & & $80-150$ & 10YR $7 / 6$ & 10YR $6 / 6$ \\
\hline \multirow{3}{*}{4} & & & & $0-30$ & 10YR $8 / 4$ & 10YR 7/4 \\
\hline & $284124.9 / "$ & & & $30-80$ & 10YR 7/6 & 10YR $6 / 6$ \\
\hline & & & & $80-150$ & 10YR $7 / 6$ & 10YR 6/6 \\
\hline \multirow{3}{*}{5} & & & & $0-40$ & 10YR 8/4 & 10YR $7 / 4$ \\
\hline & 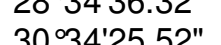 & & & $40-100$ & 10YR 7/6 & 10YR $6 / 6$ \\
\hline & & & & $100-150$ & 10YR $7 / 6$ & 10YR $6 / 6$ \\
\hline \multicolumn{7}{|c|}{ Upper rubble terraces } \\
\hline \multirow{4}{*}{6} & & \multirow{16}{*}{$\begin{array}{l}\text {-Gently undulating, } \\
\text {-Gently sloping, } \\
\text {-Gravels with } \\
\text { desert varnish }\end{array}$} & \multirow{16}{*}{$\begin{array}{l}\text {-Slight, } \\
\text {-Excess. }\end{array}$} & $0-25$ & 10YR $7 / 6$ & 10YR $6 / 6$ \\
\hline & $28^{\circ} 45^{\prime} 21.33^{\prime \prime}$ & & & $25-50$ & 10YR $7 / 6$ & 10YR 6/6 \\
\hline & $30^{\circ} 39^{\prime} 14.66^{\prime \prime}$ & & & $50-80$ & 10YR $7 / 6$ & 10YR $6 / 6$ \\
\hline & & & & $80-110$ & 10YR 6/6 & 10YR $5 / 8$ \\
\hline \multirow{4}{*}{7} & & & & $0-35$ & 10YR 7/6 & 10YR $6 / 6$ \\
\hline & $28^{\circ} 43^{\prime} 04.89^{\prime \prime}$ & & & $35-90$ & $10 \mathrm{YR} 7 / 6$ & 10YR $6 / 6$ \\
\hline & $30^{\circ} 37^{\prime} 39.39 "$ & & & $90-110$ & 10YR $7 / 6$ & 10YR $6 / 6$ \\
\hline & & & & $110-150$ & 10YR $7 / 6$ & 10YR $6 / 6$ \\
\hline \multirow{3}{*}{8} & $28^{\circ} 37^{\prime} 05.60^{\prime \prime}$ & & & $0-40$ & 10YR 6/6 & 10YR 5/6 \\
\hline & 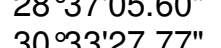 & & & $40-95$ & 10YR 5/8 & 10YR 4/6 \\
\hline & $303327.1 /$ & & & $95-150$ & $10 Y R 5 / 8$ & $10 Y R$ 4/6 \\
\hline 0 & $28^{\circ} 29^{\prime} 49.85^{\prime \prime}$ & & & $0-30$ & 10YR 7/6 & 10YR $6 / 6$ \\
\hline$y$ & $30^{\circ} 32^{\prime} 44.08^{\prime \prime}$ & & & $30-110$ & 10YR 6/8 & 10YR $5 / 8$ \\
\hline & & & & $0-40$ & 10YR 7/6 & 10YR 6/6 \\
\hline 10 & 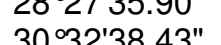 & & & $40-100$ & 10YR 7/4 & 10YR 6/6 \\
\hline & & & & $100-150$ & 10YR 7/4 & 10YR $6 / 6$ \\
\hline & & Moderate rt & ble terraces & & & \\
\hline & & & & $0-20$ & 10YR 7/6 & 10YR $6 / 6$ \\
\hline & $30^{\circ} 32^{\prime} 05.27^{\prime \prime}$ & & & $20-55$ & 10YR 7/6 & 10YR 6/6 \\
\hline 11 & $30^{\circ} 40^{\prime} 26.77^{\prime \prime}$ & -Almost flat to & & $55-100$ & 7.5YR 6/6 & 7.5 YR $5 / 6$ \\
\hline & & gently undulating, & & $100-150$ & 7.5YR 6/6 & 7.5YR 5/6 \\
\hline & & -Nearly level to & -Slight, & $0-50$ & 10YR 8/4 & 10YR $7 / 4$ \\
\hline 12 & 283639.02 & gently sloping, & -Excess. & $50-100$ & 10YR 8/4 & 10YR $7 / 4$ \\
\hline & & -Desert pavement & & $100-150$ & 10YR 7/6 & 10YR $6 / 6$ \\
\hline & & of gravels & & $0-30$ & 10YR 7/6 & 10YR 6/6 \\
\hline 13 & $30^{\circ} 37^{\prime} 06.07^{\prime \prime}$ & & & $30-90$ & 7.5YR 6/6 & 7.5YR 5/6 \\
\hline & & & & $90-150$ & 7.5YR 6/6 & 7.5YR 5/6 \\
\hline
\end{tabular}


Table (2). Continued.

\begin{tabular}{|c|c|c|c|c|c|c|}
\hline \multirow[b]{2}{*}{ Profile No. } & \multirow{2}{*}{$\begin{array}{l}\text { Lat. (N) } \\
\text { Long. (E) }\end{array}$} & \multirow{2}{*}{$\begin{array}{l}\text {-Topography, } \\
\text {-Slope, } \\
\text {-Surface cover }\end{array}$} & \multirow{2}{*}{$\begin{array}{l}\text {-Erosion, } \\
\text {-Drainage }\end{array}$} & \multirow{2}{*}{$\begin{array}{l}\text { Depth } \\
\text { (cm) }\end{array}$} & \multicolumn{2}{|c|}{ Soil color } \\
\hline & & & & & Dry & Moist \\
\hline \multicolumn{7}{|c|}{ Lower rubble terraces } \\
\hline \multirow{4}{*}{14} & & \multirow{7}{*}{$\begin{array}{l}\text {-Almost flat, } \\
\text {-Nearly level, } \\
\text {-Grit with common } \\
\text { fine gravels }\end{array}$} & \multirow{7}{*}{$\begin{array}{l}\text {-Slight, } \\
\text {-Excess. }\end{array}$} & $0-40$ & 10YR 5/8 & 10YR 4/6 \\
\hline & $28^{\circ} 44^{\prime} 31.55^{\prime \prime}$ & & & $40-60$ & 10YR 5/8 & 10YR $4 / 6$ \\
\hline & $300^{\circ} 1$ '30.10" & & & $60-85$ & 10YR 5/8 & 10YR 4/6 \\
\hline & & & & $85-120$ & 10YR 6/4 & 10YR $5 / 4$ \\
\hline \multirow{3}{*}{15} & & & & $0-50$ & 10YR 7/6 & 10YR 5/8 \\
\hline & 28 & & & $50-100$ & 10YR 6/6 & 10YR $5 / 8$ \\
\hline & & & & $100-150$ & 10YR 6/6 & 10YR $5 / 8$ \\
\hline \multicolumn{7}{|c|}{ Old river terrace } \\
\hline \multirow{3}{*}{16} & & \multirow{6}{*}{$\begin{array}{l}\text {-Undulating } \\
\text {-Sloping } \\
\text {-Desert } \\
\text { pavement }\end{array}$} & \multirow{6}{*}{$\begin{array}{l}\text {-Moderate, } \\
\text {-Excess. }\end{array}$} & $0-50$ & 10YR 7/6 & 10YR 6/6 \\
\hline & $\begin{array}{l}28444^{\circ} 3.09^{\prime \prime} \\
30^{\circ} 41^{\prime} 16.56 "\end{array}$ & & & $50-100$ & 10YR 7/6 & 10YR 6/6 \\
\hline & & & & $100-150$ & 10YR 5/8 & 10YR 4/6 \\
\hline \multirow{3}{*}{17} & & & & $0-40$ & 10YR 6/4 & 10YR 5/4 \\
\hline & $28^{\circ} 40^{\prime} 36.69^{\prime \prime}$ & & & & 10YR 5/8 & 10YR 4/6 \\
\hline & $30^{\circ} 37$ & & & $\begin{array}{c}90-130 \\
130-150\end{array}$ & $\begin{array}{l}\text { 7.5YR 5/8 } \\
10 Y R \text { 7/6 }\end{array}$ & 7.5YR 4/6 \\
\hline
\end{tabular}

Table (3). Physical, and chemical soil properties in the studied area.

\begin{tabular}{cccccccc}
\hline Profile No. & $\begin{array}{c}\text { Depth } \\
(\mathbf{c m})\end{array}$ & $\begin{array}{c}\text { Gravel } \\
(\%)\end{array}$ & $\begin{array}{c}\text { Texture } \\
\text { class }\end{array}$ & $\mathbf{p H}$ & $\begin{array}{c}\text { EC } \\
\mathbf{d S} / \mathbf{m}\end{array}$ & $\begin{array}{c}\mathbf{C a C O}_{3} \\
\%\end{array}$ & $\begin{array}{c}\text { Gypsum } \\
\%\end{array}$ \\
\hline \multirow{2}{*}{1} & $0-20$ & 6.67 & $\mathrm{~S}$ & 7.6 & 6.91 & 12.8 & nil \\
& $20-35$ & 1.79 & $\mathrm{~S}$ & 7.8 & 4.21 & 9.9 & nil \\
\hline \multirow{2}{*}{2} & $0-25$ & 6.12 & $\mathrm{~S}$ & 7.6 & 3.54 & 16.5 & nil \\
& $25-45$ & 6.09 & $\mathrm{~S}$ & 7.4 & 2.97 & 18 & nil \\
\hline \multirow{3}{*}{3} & $0-20$ & 7 & $\mathrm{~S}$ & 7.5 & 4.78 & 20.2 & 15.5 \\
& $20-80$ & 12.05 & LS & 7.8 & 11.08 & 12.3 & 10.98 \\
& $80-150$ & 18.33 & GrLS & 7.5 & 5.34 & 19 & 12.48 \\
\hline \multirow{3}{*}{4} & $0-30$ & 6.67 & S & 7.8 & 14.04 & 8 & 22.5 \\
& $30-80$ & 8.33 & LS & 8 & 9.91 & 6.9 & 21.9 \\
& $80-150$ & 10.53 & LS & 8 & 8.91 & 7.7 & 20 \\
\hline \multirow{2}{*}{5} & $0-40$ & 8.11 & LS & 8 & 9.42 & 10.2 & 13.99 \\
& $40-100$ & 9.26 & S & 8 & 8.00 & 16 & 13.82 \\
& $100-150$ & 16.29 & GrS & 7.6 & 8.50 & 22.7 & 10.98 \\
\hline \multirow{2}{*}{6} & $0-25$ & 8 & S & 7.7 & 15.52 & 12.2 & 9.16 \\
& $25-50$ & 20.5 & GrS & 7.8 & 26.53 & 10.1 & 18.94 \\
& $50-80$ & 26.6 & GrS & 7.9 & 9.77 & 9.9 & 21.53 \\
& $80-110$ & 36.36 & GrS & 7.9 & 7.04 & 11.9 & 9.69 \\
\hline
\end{tabular}


Table (3). Continued.

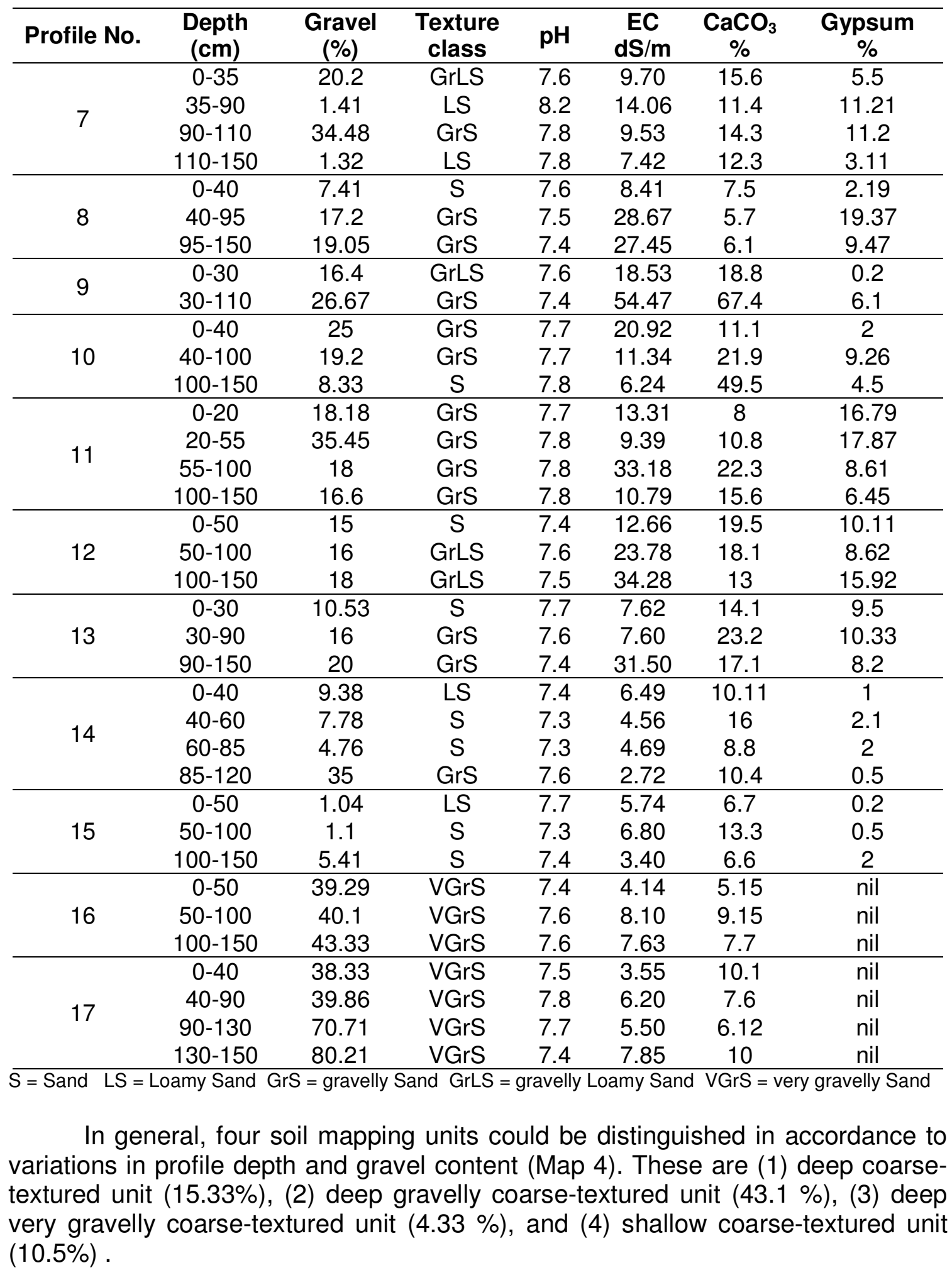




\section{Agricultural land capability using MicroLEIS}

Results of the agricultural land capability evaluation generated by CERVATANA model constituent of MicroLEIS DSS are presented in Table 4 and Map 5. They include land capability classes and associated limitations of the studied soils representing different landforms.

Two land capability classes were recognized, "Moderate Capability, S3" and "Non-Productive, N". Lands of moderate capability have two subclasses abbreviated as "S3 I" referring to moderate capability with slight constrain severity, and "S3 Ir" including soils of moderate capability affected by sever soil constrains and erosion risk. S3 I subclass include soils of alluvial fans and outwash plains, lower rubble terraces, and partially old river terraces, which have moderate limitation regarding soil factor. Meanwhile S3 Ir subclass has considerable limitations linked to topographic (slope), edaphic (shallow profile, poorly drainage, and/or high gravel content), or climatic factors. They include soils of pediment and partially old river terraces. These substantially reduce the range of possible crops and the productive capability. Management techniques are more difficult to be applied due to higher costs. Intensive practices are necessary - and sometimes special conservation practices to maintain a continued productivity. Non-productive land $(\mathrm{N} \mathrm{I})$ includes soils of upper and moderate rubble terraces. They do not provide the ecological conditions necessary for agricultural crops, therefore they are recommended for pasture or forestry land utilization types. They may need very different management and conservation practices to overcome its topographic (slope), edaphic (high salinity and gravels), or climatic deficiencies.

\section{D- Priorities of agricultural utilization}

To define the best agricultural utilization at El-Minia desert fringe, a Priorities of Agricultural Utilization Model (PAUM) was designed and processed using the GIS spatial modeling environment. The most effective factors included in that model to determine priorities of agricultural utilization under the studied area conditions could be concluded as geomorphological units, soil units, capability classes, slope gradient, water availability and quality and roads network.

Four steps were incorporated to process data and information using PAUM, these are:

1- Data input,

2- Extract and classify new information in accordance to common scales, where the higher values were given to the more capable location for agricultural use,

3- Weighting the classified data according to a percentage of their influence in the process.

4- Combining the data using conditional statements and data filtering to produce a graded map of agricultural use priority. 


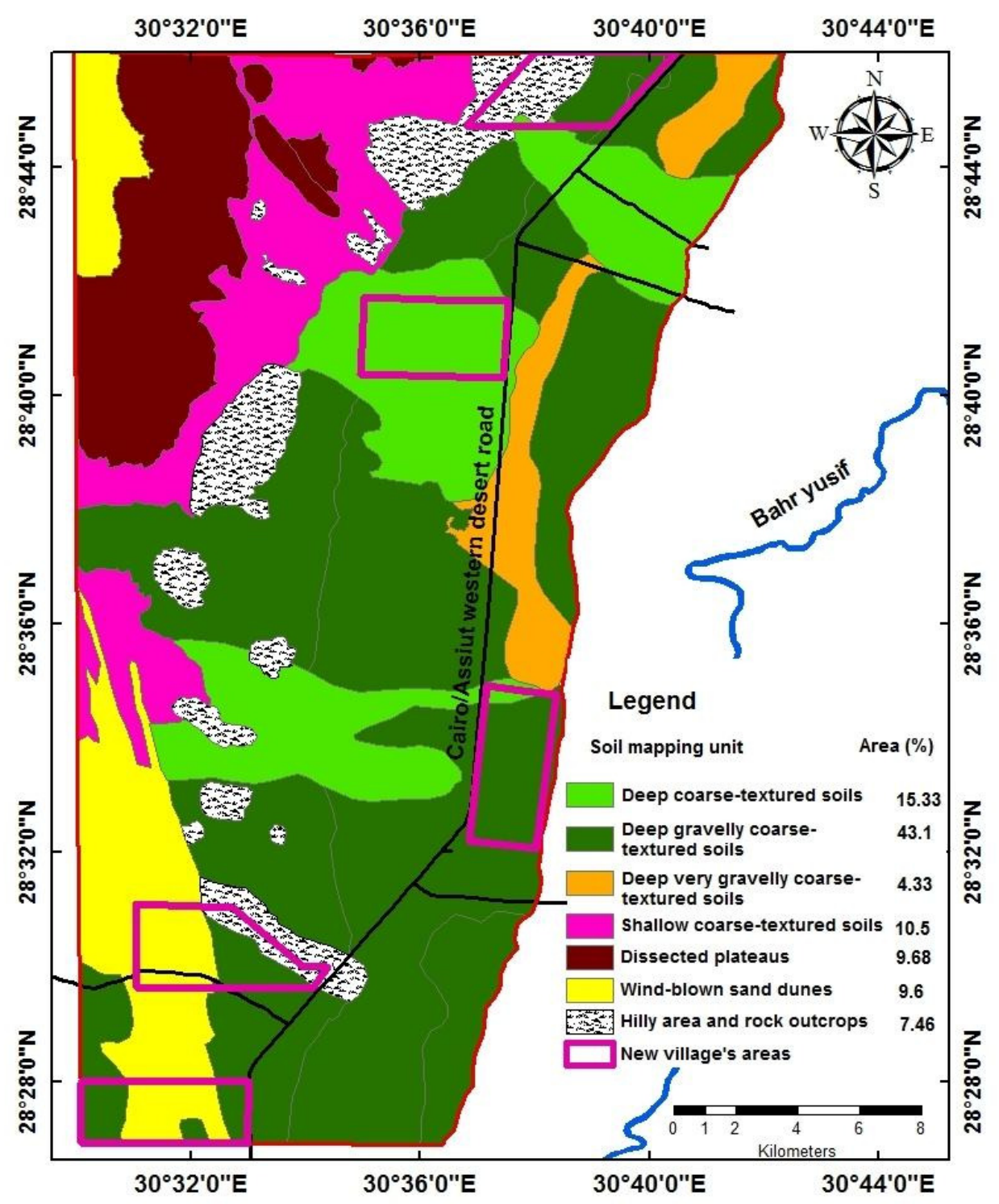

Map (4). Soil mapping units of the studied area.

PAUM resulted in four grades or categories of the agricultural utilization priorities at El-Minia desert fringe shown in Map 6. The first priority extent over $25.84 \%$ of the total area and belongs mainly to soils of alluvial fans and outwash plains, lower rubble terraces, and partially old river terraces, while the second priority cover $11.62 \%$ of the whole area representing soils of pediment and partially old river terraces. The third priority occupies $45.40 \%$ of the area and includes soils of upper and moderate rubble terraces in addition to sand dune. Unsuitable soils represent the fourth priority which extends over $17.14 \%$ of the entire terrain including dissected plateaus and hilly areas. 
Table (4). Land capability classes in accordance to processed land characteristics in the study area.

\begin{tabular}{|c|c|c|c|c|c|c|c|c|c|c|c|c|}
\hline $\begin{array}{l}\text { Prf. } \\
\text { No. }\end{array}$ & Slope & $\begin{array}{c}\text { Depth } \\
\text { cm }\end{array}$ & $\begin{array}{l}\text { Text. } \\
\text { class }\end{array}$ & $\begin{array}{l}\text { Gr. } \\
\%\end{array}$ & $\begin{array}{c}\mathrm{EC} \\
\mathrm{dS} / \mathrm{m}\end{array}$ & Drainage & $\begin{array}{c}\text { Soil } \\
\text { erosion }\end{array}$ & Vegetation & Erosiv. & Water deff. & Frost & class \\
\hline \multicolumn{13}{|c|}{ Pediment } \\
\hline 1 & & 35 & $S$ & 6.7 & 6.9 & Poorly & Moderate & Nil & Slight & Low & Slight & S3 Ir \\
\hline 2 & Sloping & 45 & S & 6.1 & 3.5 & Poorly & Moderate & Nil & Slight & Low & Slight & S3 Ir \\
\hline \multicolumn{13}{|c|}{ Alluvial fans and outwash plains } \\
\hline 3 & & 150 & $S$ & 14.0 & 7.1 & Excessively & Slight & Moderate & Slight & Low & Slight & S3 I \\
\hline 4 & Nearly & 150 & $S$ & 10.0 & 9.8 & Excessively & Slight & Moderate & Slight & Low & Slight & S3 I \\
\hline 5 & & 150 & LS & 15.0 & 12.0 & Excessively & Slight & Moderate & Slight & Low & Slight & S3I \\
\hline \multicolumn{13}{|c|}{ Upper rubble terraces } \\
\hline 6 & & 110 & GrS & 25.0 & 20.0 & Excessively & Slight & Moderate & Slight & Low & Slight & N I \\
\hline 7 & & 150 & GrLS & 25.0 & 13.0 & Excessively & Slight & Nil & Slight & Low & Slight & N I \\
\hline 8 & Gently & 150 & GrS & 20.0 & 14.0 & Excessively & Slight & Nil & Slight & Low & Slight & N I \\
\hline 9 & & 110 & GrLS & 20.0 & 18.5 & Excessively & Slight & High & Slight & Low & Slight & N I \\
\hline 10 & & 150 & GrS & 25.0 & 14.0 & Excessively & Slight & High & Slight & Low & Slight & N I \\
\hline \multicolumn{13}{|c|}{ Moderate rubble terraces } \\
\hline 11 & Nearly & 150 & GrS & 25.0 & 20.0 & Excessively & Slight & Nil & Slight & Low & Slight & N I \\
\hline 12 & level to & 150 & GrS & 20.0 & 20.0 & Excessively & Slight & High & Slight & Low & Slight & N I \\
\hline 13 & $\begin{array}{l}\text { gently } \\
\text { sloping }\end{array}$ & 150 & GrS & 25.0 & 19.0 & Excessively & Slight & High & Slight & Low & Slight & N I \\
\hline \multicolumn{13}{|c|}{ Lower rubble terraces } \\
\hline 14 & Nearly & 120 & LS & 10.0 & 6.5 & Excessively & Slight & High & Slight & Low & Slight & S3 I \\
\hline 15 & level & 150 & $\mathrm{~S}$ & 5.0 & 5.7 & Excessively & Slight & High & Slight & Low & Slight & S3I \\
\hline \multicolumn{13}{|c|}{ Old river terrace } \\
\hline 16 & & 150 & VGrS & 50.0 & 5.4 & Excessively & Moderate & Nil & Slight & Low & Slight & S3 Ir \\
\hline 17 & Sloping & 150 & VGrS & 45.0 & 5.0 & Excessively & Moderate & High & Slight & Low & Slight & S3 I \\
\hline $\begin{array}{l}\text { Text } \\
\text { GrL }\end{array}$ & ture & 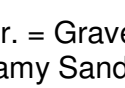 & $\begin{array}{l}\text { Er } \\
\text { VC }\end{array}$ & $=\mathrm{El}$ & $\begin{array}{l}y \\
\text { velly }\end{array}$ & f. = deficiency & $S=$ Sand & LS = Loar & nd & Gra & & \\
\hline
\end{tabular}




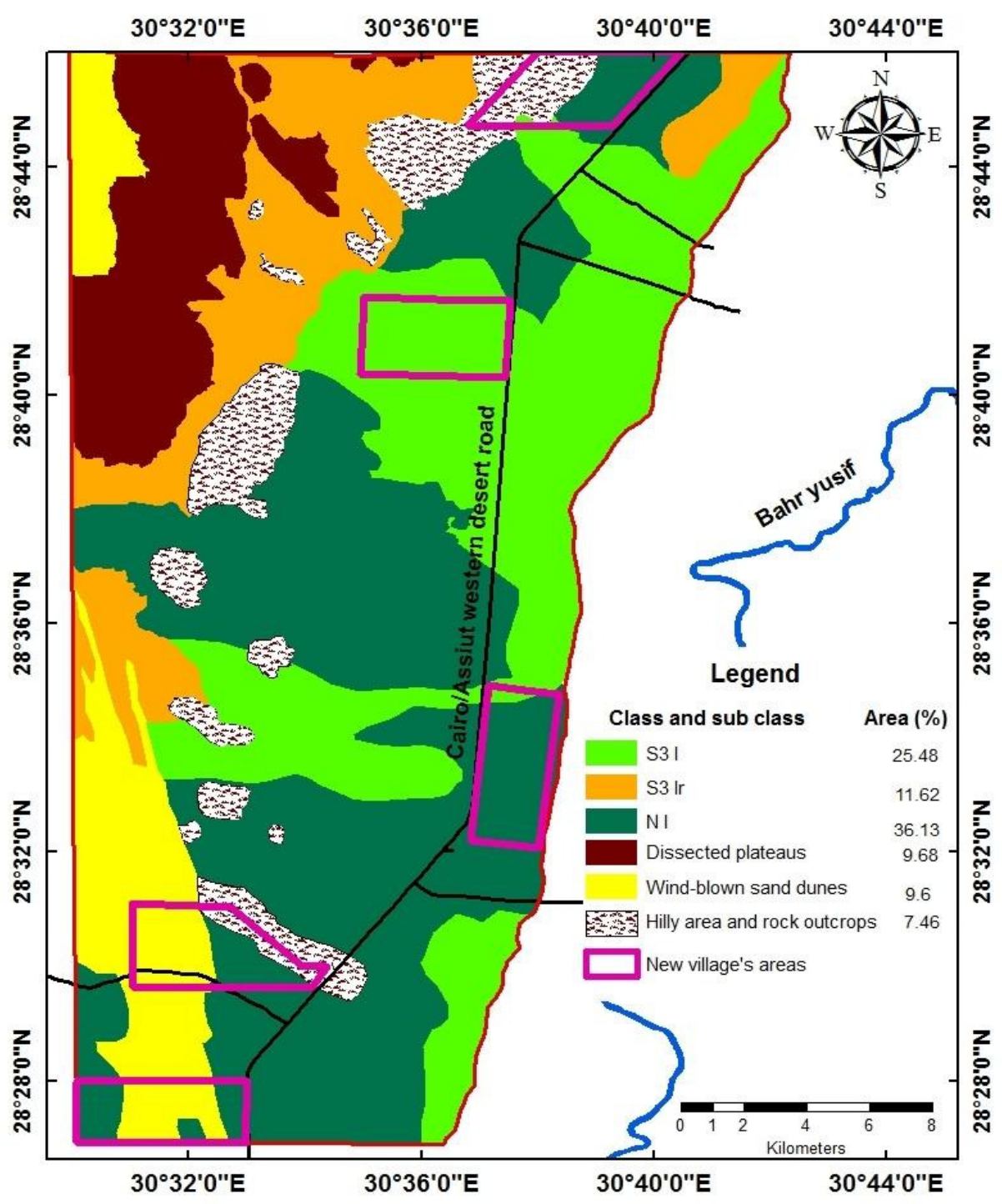

Map (5). Land capability classes of the studied area.

In conclusion, soils of the immediate western desert fringe of El-Minia are affected by the western rocky areas, which rendered those terrace soils to contain relatively high content of carbonate and gypsum. Only new AshShaykh Mas'ud village belongs to the first priority for agricultural utilization, while, the rest villages under investigation classified as third priority. This may be present an important query around the selection of these new villages locations. Therefore, the study is considered of vital importance for decision makers and for the management of natural resources in this desert fringe of El-Minia. Such investigation is aggressively needed before the planning stage of the national schemes of agrarian 
extension. On the other hand, integrating MicroLEIS Decision Support System DSS with spatial analyst in a GIS framework for mapping and analysis allows the use of spatial techniques to expand land evaluation results through geo-referenced map units.

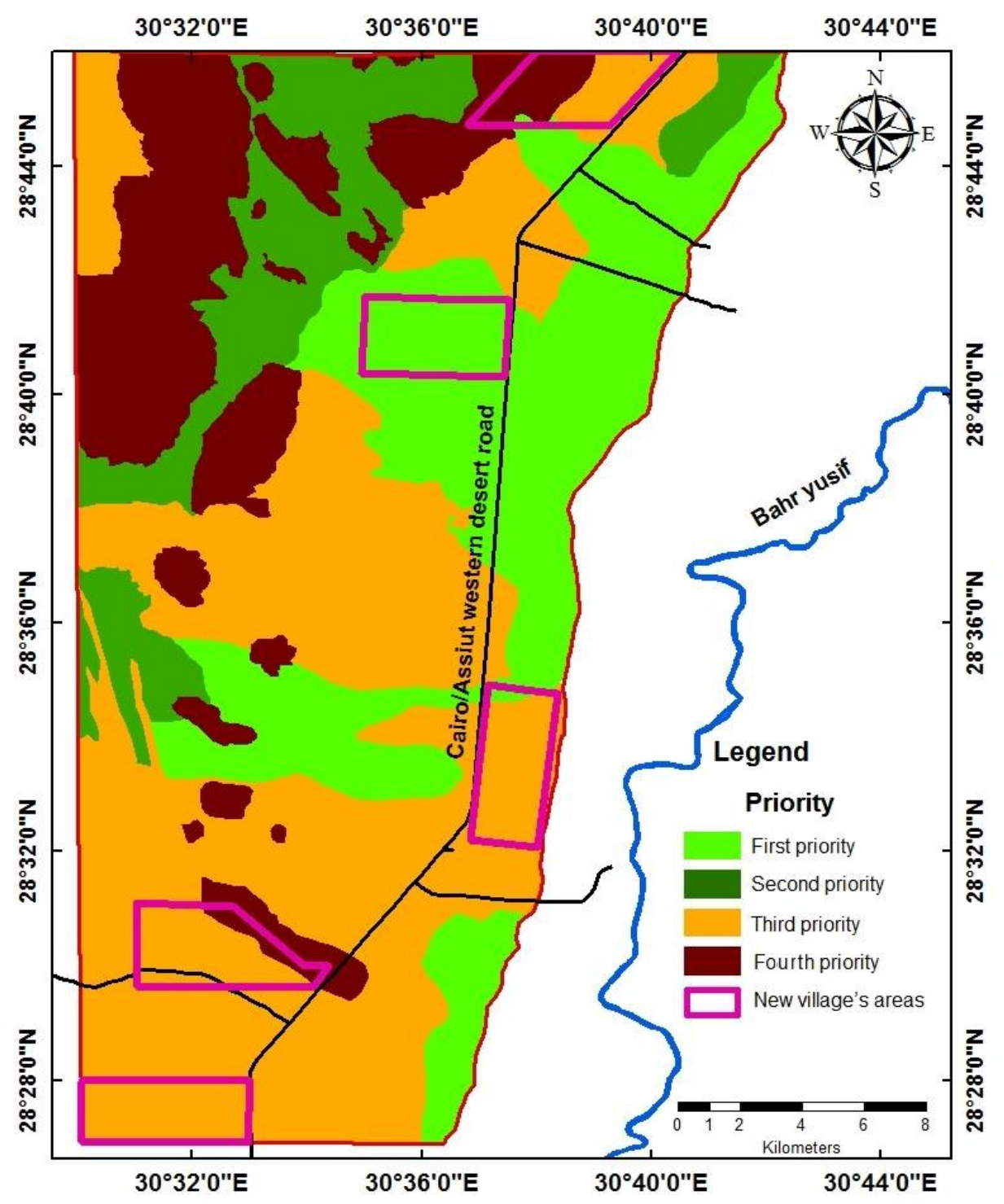

Map (6). Land priority of agricultural utilization at the studied area. 


\section{REFERENCES}

Abu El-Izz. (2000). Landforms of Egypt. American University, Press, Cairo, Egypt, $281 \mathrm{p}$.

De la Rosa, D., Moreno J.A., Garcia, L.V. (1992). MicroLEIS: a microcomputerbased Mediterranean land evaluation information system. Soil Use Manag, 8: 89-96.

De la Rosa, D., Mayol, F., Fernandez, M.,and Diaz-Pereira, E. (2004). A land evaluation decision support system (MicroLEIS DSS) for agricultural soil protection with special reference to the Mediterranean region. Environ Model Software, 19: 929-942.

Dent, D. and Young, A. (1981). Soil survey and land evaluation. Allen and Unwin Ltd. Londres.

DRC Staff. (2014). Internal report for scientific program on Monitoring and Evaluation of Natural and Human resources, of east and west desert fringes of Upper Egypt governorates, first El-Minia Governorate, soils studies of some new village's areas of El-Minia Governorate eastern desert fringes, DRC, Cairo, Egypt.

DRC Staff. (2016). Internal report for scientific program on Monitoring and Evaluation of Natural and Human resources, of east and west desert fringes of Upper Egypt governorates, first El-Minia Governorate, soils studies of some new village's areas of El-Minia Governorate western desert fringes, DRC, Cairo, Egypt.

Egyptian General Petroleum Corporation - Conco Coral. (1987). Geological Map of Egypt, sheet of El-Minia, Scale 1:500000.

Egyptian Meteorological Authority. (2009). Climate Atlas of Egypt - El-Minia station, Cairo, Egypt.

ERDAS, Inc. (2010). ERDAS Field Guide (ERDAS Imagine).EightEdition.Atlantic, Georgia, USA.

ESRI. (2010). Arc GIS Spatial Analyst : Advanced-GIS Spatial Analysis Using Raster and vector data, ESRI, 380 New york, USA.

FAO. (1976). A framework for land evaluation. Soils Bulletin 32. Rome.

FAO.(1990). Guide lines for soil profile description. FAO, Rome.

FAO. (2007). Land evaluation, towards a revised framework.

Klingebiel, A.A. and Montgmery, P.H. (1961). Land capability classification. USDA agricultural Handbook 210. US Government Printing Office, Washington, DC.

ONERN. (1982). Clasificación de lastierrasdel Peru. Pub.Ofic.Nac.Ev. Rec. Nat. Lima.

Said, R. (1993). Geology of Egypt: Netherlands, A. A. Balkema, Rotterdam.

USDA, Soil Survey Staff. (2010). Key's to Soil Taxonomy. A basic system of soil classification for making and interpreting soil surveys, U.S. Department of Agriculture, Natural Resources Conservation Service, U.S.D.A.

USDA, Soil Survey Staff. (2014). Kellogg Soil Survey Laboratory Methods Manual. Soil Survey Investigations Report No. 42, Version 5.0. R. Burt and 
Soil Survey Staff (ed.). U.S. Department of Agriculture, Natural Resources Conservation Service.

Verheye, W. (1986). Land evaluation and land use planning in the EEC. CEC-DG.

VI. Draft. Rep. Brussels.

الملخص العربى

أولويات الاستغلال الزراعى لبعض المناطق الجديدة بالظهيز الصحراوى

لمحافظة المنيا - مصر

طاهر مصطفى حامد يوسف و محمد عزت عبد الهادى خليفة و أحمد سيد أحمد

قسم البيدولوجى - شعبة مصادر المياهوالأراضى الصحراوية - مركز بحوث الصحراء

نظـرا لتآكل الرقعـة الزراعيـة بشكل مستمر فـإن الضـرورة تحتت سـرعة البحث عن مسـاحات أرضـية جديدة بالأقـاليم الصحراوية تكون مناسبة لتتفيذ مشروعات التتمية الزراعية المتواصلة بها. لذا تهدف هذه الدراعة الدراسة إلى تحديد أولويات

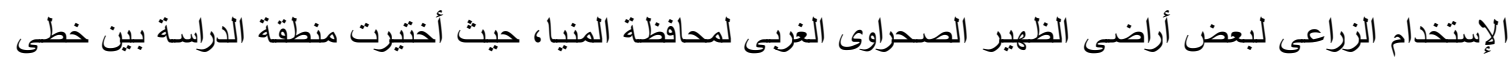

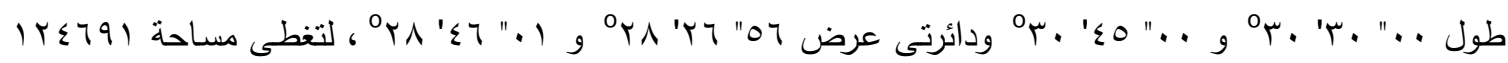

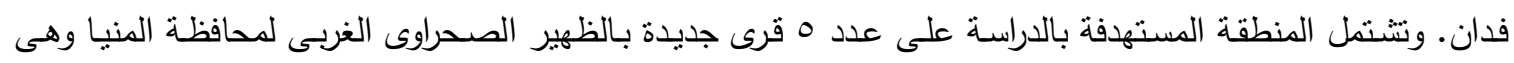

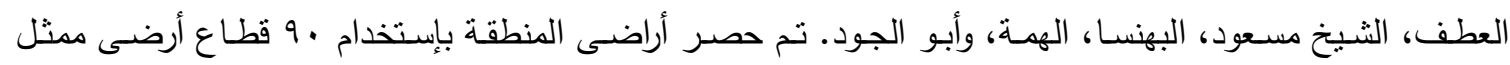

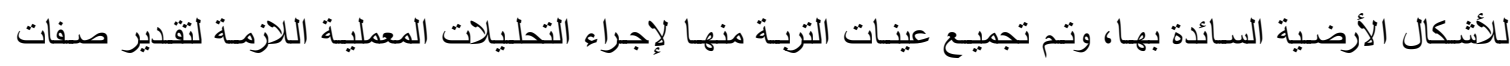
وخصائص الثربة، وأختير منها IV قطاع تربة ممثل بالدراسة الحالية. وبناءا على الدراسة الحقلية والتحليلات المعلية

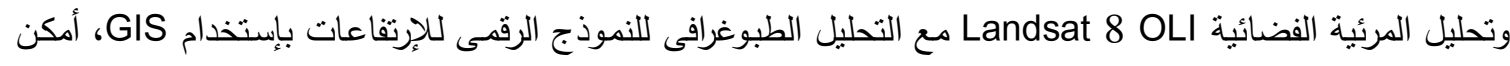

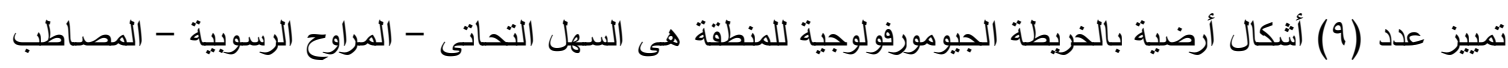
المجواه العليا والوسطى والدنبا - المصـاطب النهرية القديمة - الهضبة الجيريـة المقسمة - الكثبان الرملية - التلال الصخرية. كما أمكن تقسيم نربـة هذه الأشكال الأرضية لعدد (7) تحت مجموعـة عظمى طبقا للتصنيف الأمريكى

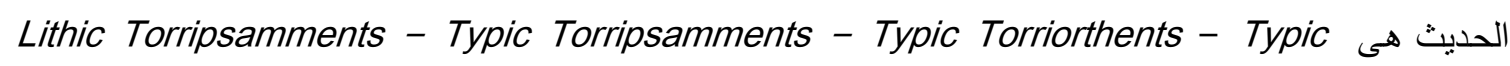
Haplogypsids - Calcic Haplosalids - Typic Haplocalcids

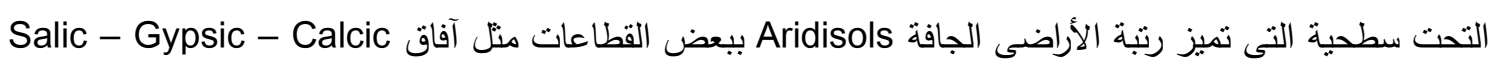

كذلك تم تقييم القدرة الإنتاجية للأراضى بإستخدام نموذج CERVATANA لبرنامج MicroLEIS حيث وجد

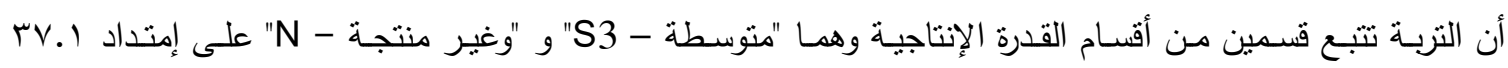

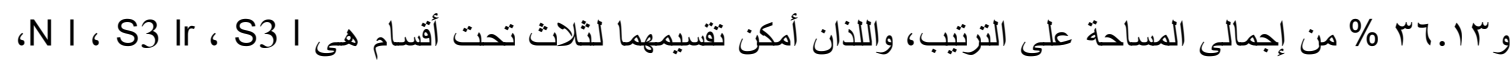
تبعا لنوع وشدة المحدات الأرضية السائدة. وحددت الدراسة أنواع ومواقع المحدات الأرضية ببعض المضات المساحات بالمنطقة 
والتى تركزت فى وعورة السطح وشدة المبول - ضحالة قطاع التربة - سوء الصرف - إرتفاع الملوحة - إرتفاع نسبة

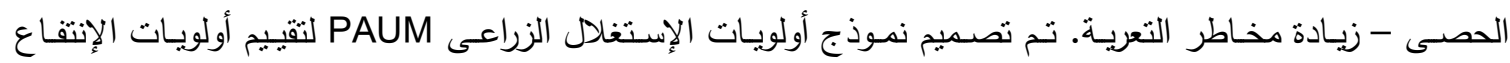

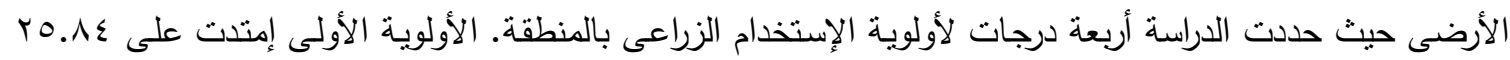

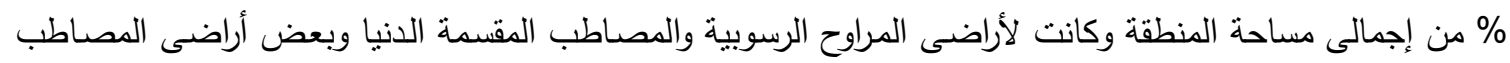

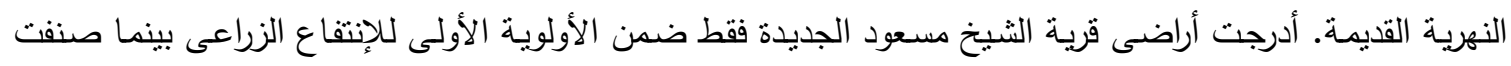

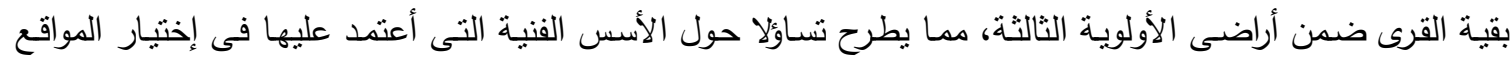
الحالية للقرى الجديدة بالظهير الصحراوى الغربى لمحافظة المنيا. وفى العموم قدمت الدراسة دلائل كمية قد تكون من الإلهابه

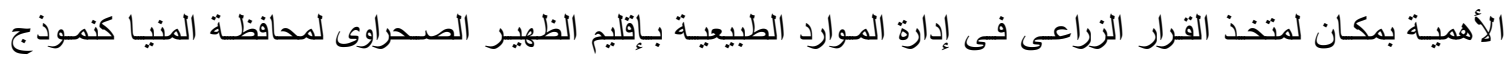

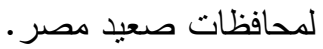

